http://doi.org/10.35784/iapgos.2003

\title{
FREQUENCY MODULATION APPROACH BASED ON SPLIT-RING RESONATOR LOADED BY VARACTOR DIODE
}

\author{
Dmytro Vovchuk, Serhii Haliuk, Pavlo Robulets, Leonid Politanskyi \\ Yuriy Fedkovych Chernivtsi National University, Department of Radio Engineering and Information Security, Chernivtsi, Ukraine
}

Abstract. In the paper, an approach to frequency modulation is presented using a split-ring resonator (SRR) loaded by a varactor diode. The modulation occurs due to the continuous time variation of capacitance of the varactor diode via changing of its bias voltage by the signal which is necessary to modulate. The modulation signal is used for bias voltage. As a source of a carrier signal, one more extra magnetic loop antenna is utilized which is coupled with the SRR via near-field interaction. Investigation of two types of signals (harmonic and chaotic) was performed for modulation in the paper. It is shown that it is possibile to provide the frequency modulation with deviation $\Delta f_{d}= \pm 80 \mathrm{MHz}$ which covers the frequency range 0.95 ... 1.11 GHz for a $1 \mathrm{GHz}$ carrier signal when a SMV1231 varactor diode is used. The major advantages of the suggested approach are the very simple design and ability to easily define the required values of frequency deviation through tuning of the bias voltage magnitude range of the varactor diode. Therefore, the presented investigation and results can be useful in the manufacturing of low-cost radio components.

Keywords: frequency modulation, varactor diode, split-ring resonator, frequency range, frequency deviation

\section{ZASADA MODULACJI CZESTOTLIWOŚCIOWEJ NA BAZIE REZONATORA Z DZIELONYM PIERŚCIENIEM OBCIĄŻONEGO DIODĄ POJEMNOŚCIOWĄ}

\begin{abstract}
Streszczenie. W pracy zaproponowano zasade modulacji czestotliwości z wykorzystaniem rezonatora z dzielonym pierścieniem (SRR) obciażonego dioda pojemnościowa. Proces modulacji zachodzi poprzez ciagła zmianę pojemności diody pojemnościowej, która z kolei następuje poprzez zmianę napięcia polaryzacji. Sygnat modulujący stuży jako napięcie polaryzacji. Źródtem sygnału nośnego jest dodatkowa antena magnetyczna, która oddziałuje poprzez bliskie pole magnetyczne z SRR. W pracy przeprowadzono badania w których jako sygnat modulujacy zostaty wykorzystane dwa rodzaje sygnałów: harmoniczny i deterministyczny chaotyczny. Wykazano, że przy zastosowaniu diody pojemnościowej SMV1231 i częstotliwości sygnatu nośnego 1 GHz możliwe jest zapewnienie modulacji częstotliwości z odchyleniem $4 f_{d}= \pm 80 \mathrm{MHz} w$ paśmie częstotliwości $0,95 \ldots 1,11$ GHz. Zaletami proponowanej metody modulacji sa bardzo prosta konstrukcja i możliwość łatwego ustawienia żądanej wartości odchylenia częstotliwości poprzez dostosowanie zakresu wartości napięcia przyłożonego do diody pojemnościowej. Przedstawione badania i uzyskane wyniki moga być przydatne w produkcji tanich komponentów radiowych.
\end{abstract}

Słowa kluczowe: modulacja częstotliwości, dioda pojemnościowa, rezonator z dzielonym pierścieniem, zakres częstotliwości, odchylenie częstotliwości

\section{Introduction}

An SRR is a kind of left-handed metamaterial, characterized by a negative value of permeability $\mu[5,14]$. Such a unique physical property was invented and described in [24] and is totally different from all natural materials where the permittivity and permeability are strongly positive. There are many approaches to manufacture both single SRRs and their arrays to utilize them at frequency ranges up to nanometer dimensions [7-8, 18, 28]. For instance, the microwave frequency applications of SRRs can be implemented by chemical etching on a dielectric substrate, as shown in Fig. 1a. Due to their high sensitivity, single SRRs [6-7] or surfaces based on SRR arrays $[13,19,21]$ are successfully used for different applications such as a microwave sensor of small liquid inclusions [13, 21], the monitoring of organic tissue [19], permittivity sensors $[4,11]$, etc.

All applications of SRRs are possible due to the variety of their shape parameters including split width, gap distance, metal width and soldered capacitors or inductors as well as different resonator structures that are shown in detail in [1, 15]. Manipulating these constructive parameters allows the changing of SRRs' resonant characteristics which can be expressed via S-parameters. Each of the described approaches opens a lot of ways to tune the resonance frequency as required.

The physical dimensions of metamaterial components are predefined. For instance, in [26] a metamaterial was suggested that consists of asymmetric ring resonators which provide tuning by resonance frequencies via their shape deformation under the impact of thermal processes of the IR frequency range. Also, in [12], the dependence of the resonance values changing is shown through mechanical changing due to a ring stretching. Such approaches are quite inconvenient and characterized a low level of reliability. At the optical frequency range, the manufacturing of hybrid modulation systems using an SRR modified by an extra layer of graphene is very promising, though more expensive. An input signal of the described approach directly depends on the magneto-optical response of the structure $[16,27]$.
The most convenient method to control the resonances of SRRs is a time-variant tuning of the capacitance, for example by switching components with different values of capacitance by transistors or pholoelements which work in key-mode and provide so-called on/off-modulation [10-11]. However, topical and quite practical at the present time is the usage of varactor diodes, that is, components which can change their capacitance based on a bias voltage in a defined magnitude range [2]. Such an approach is utilized in the manufacturing of filters [22] and metasurfaces $[9,23]$, etc. Therefore, below, we suggest and investigate the possibility of adjusting the high frequency (HF) oscillations that appear in an SRR under the outer impact of low frequency (LF) ones, and of achieving the frequency modulation of harmonic and deterministic chaotic signals.

\section{Theoretical description of SRR}

A conventional SRR (Fig. 1a) consists of two cut rings with radii $R_{\text {outer }}=\left(R_{\text {outl }}-R_{\text {in } 1}\right) / 2$ and $R_{\text {inner }}=\left(R_{\text {out } 2}-R_{\text {in } 2}\right) / 2$, where $R_{\text {out } 1}$ and $R_{\text {inl } 1}$ are the outer and inner radii of the larger ring and $R_{\text {out } 2}$ and $R_{i n 2}$ are the outer and inner radii of the smaller ring; and $w_{1}=R_{\text {out } 1}-R_{\text {in } 1}$ and $w_{2}=R_{\text {out } 2}-R_{\text {in } 2}$ are the widths of the outer and inner rings of the SRR, respectively. The distance between the outer and inner rings is $s=R_{\text {inl }}-R_{\text {out } 2}$. The gaps $g$ of each ring are rotated in a straight angle one from the other. The usual lowplanar SRR is placed onto a dielectric substrate of height $h$ and with permittivity $\varepsilon$ as shown in Fig. $1 a$.

An SRR presents a conventional oscillator that equivalently corresponds to a usual $L C$-circuit as depicted in Fig. $1 b$. However, $L$ and $C$ are the total values of inductance and capacitance depending on several components. These values can be calculated through per-unit-length capacitance and inductance using complete $K(\cdot)$ and complementary $k$ ' elliptical integrals [3, 6]:

$$
\begin{gathered}
\mathrm{C}_{\text {pul }}=4 \varepsilon_{0}\left(\frac{\mathrm{K}\left(\mathrm{k}^{\prime}\right)}{\mathrm{K}(\mathrm{k})}+\frac{\mathrm{t}}{4 \mathrm{~s}}\right) \\
\mathrm{L}_{\text {pul }}=\frac{1}{\mathrm{c}^{2} \mathrm{C}_{\mathrm{pul}}}
\end{gathered}
$$

where $c$ is the speed of light 
The total capacitance and inductance values are expressed as:

$$
\begin{gathered}
\mathrm{C}=\frac{\theta \mathrm{rC}_{\mathrm{pul}}}{4}+2 \mathrm{C}_{\mathrm{g}} \\
\mathrm{L}=\theta \mathrm{rL}_{\mathrm{pul}}+2 \mathrm{~L}_{\mathrm{g}}
\end{gathered}
$$

where $2 C_{g}=C_{1}+C_{2}$ for $C_{1}=C_{2}$ which can be calculated from [20]; $r$ is the effective radius, and $\theta$ is the effective angle appearing due to the strips' curvature. $L_{g}$ is described by Rosa's formula $[17,29]$. Finally, the resonance frequency of an SRR can be found using the well-known Thomson's formula $f=1 /[2 \pi \sqrt{ }(L C)]$.

a)
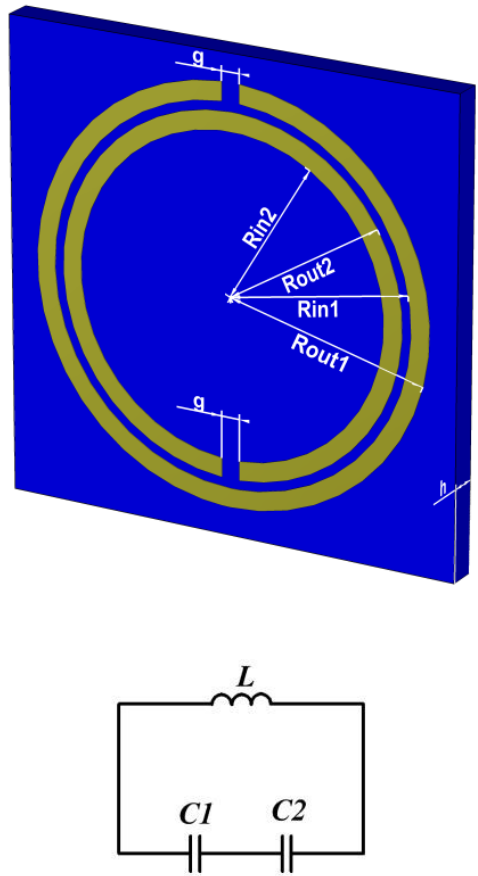

Fig. 1. The usual low-profile SRR on a dielectric substrate (a), and its equivalent LC1C2-circuit (b)

\section{Experimental measurements of the suggested modulation principle}

The suggested modulation device is presented in Fig. 2a It includes an SRR that is manufactured by chemical etching on a FR4 dielectric substrate where one of the gaps is substituted by a soldered varactor diode $V D$. This gap is connected to a modulation signal generator $(M S)$ via an SMA connector. The $m(t)$ signal provides the varying of total capacitance changing $V D$ bias voltage. In the experiment, an SMV1231 varactor diode was utilized where its capacitance can change $\Delta C=C_{U \min } \ldots C_{U \max }=2.35 \ldots 0.534 \mathrm{pF}$ for reverse voltage changing $\Delta U=U_{\min } \ldots U_{\max }=0 \ldots 7 \mathrm{~V}$ [29], where the $\min$ and $\max$ indexes indicate the values of capacitances for the minimum and maximum values of the voltages, respectively. By changing one of the capacitances from the equivalent circuit of Fig. $1 b$ and keeping in mind their serial connection, one can obtain the ratio (5) from calculations of the resonant frequency following Thomson's formula using (1)-(4):

$$
f_{U \text { min }} / f_{U \text { max }}=0.86
$$

The equivalent circuit of the modulator is shown in Fig. $2 \mathrm{~b}$ The SRR loaded by a varactor diode is presented by the resonant circuit $L 1 C 1 V D$. A source of the modulation signal $M S$ generates the LF signal (harmonic or chaotic) $m(t)$. The carrier signal $M(t)=\cos \left(2 \pi f_{C} t\right)$, where $f_{C}$ is a frequency of the carrier signal, is supported by HF signal generator $C S$. This signal, via a circulator and then through the magnetic interaction between L1 and L2, is transferred to the oscillator where the frequency modulation occurs. Then, via the $L 1 L 2$-subcircuit and circulator, the modulated signal $S(t)$ is transmitted to the communication channel. In the experimental setup, a usual magnetic loop antenna was used as the $L 1 L 2$-subcircuit.
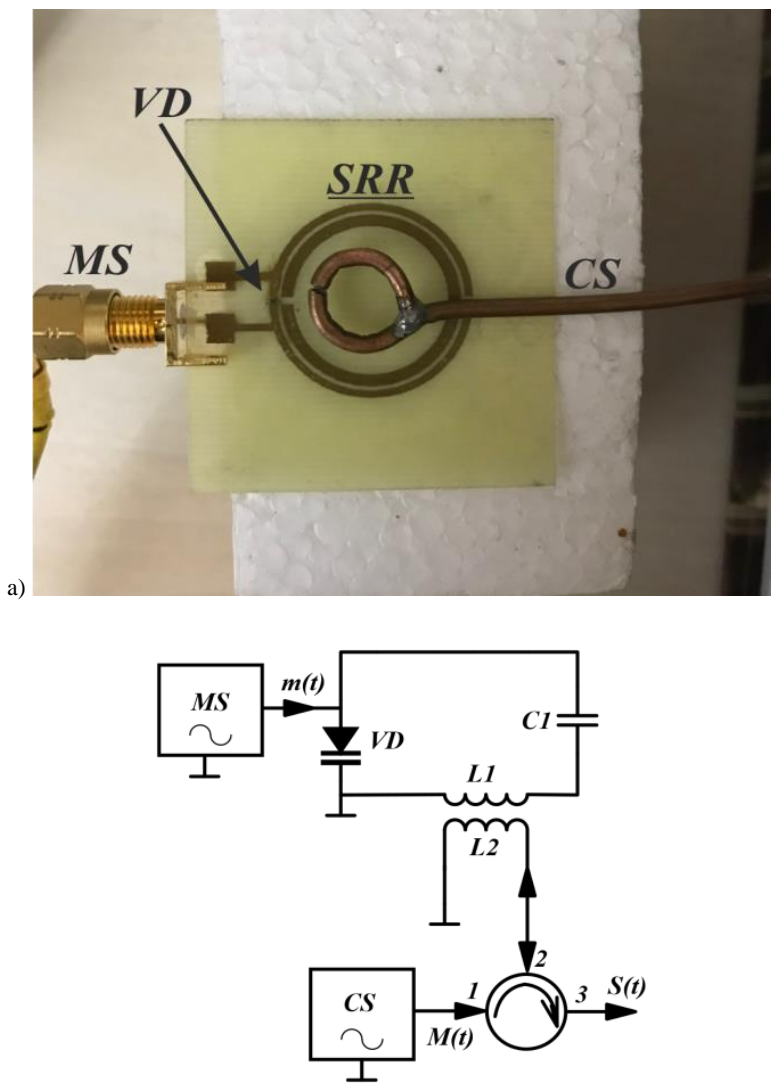

b)

Fig. 2. Experimental setup of the suggested frequency modulation principle that consists of an SRR loaded by a varactor diode and magnetic loop antenna to supply the HF carrier signal (a), and its electrical circuit which includes modulation (MS) and carrier (CS) signal generators interacting with the SRR via a strong near magnetic field (L1-L2) and circulator (b)

In order to begin the experimental investigation of the frequency modulation by the proposed approach, it is necessary to check the operational voltage range of the used varactor diode which will be further supplied to the signal $m(t)$. It was measured through the $S_{11}$-parameters of the used magnetic loop antenna. It was determined that the operating frequencies are restricted to the range of $\Delta f=0.95 \ldots 1.11 \mathrm{GHz}$ for $f_{C}=1 \mathrm{GHz}$ (the deviation value of frequency $\Delta f_{d}= \pm 80 \mathrm{MHz}$ ) for the voltage range $\Delta U=-4.0 \ldots 3.0 \mathrm{~V}$ (Fig. 3). In this case, the modulation index was $\beta=0.078$. The obtained frequency range satisfies expression (5). It is the maximum possible frequency range for the selected varactor diode and it can be tuned as required by establishing the minimum and maximum values of bias voltage. This allows the required frequency range to be controlled.

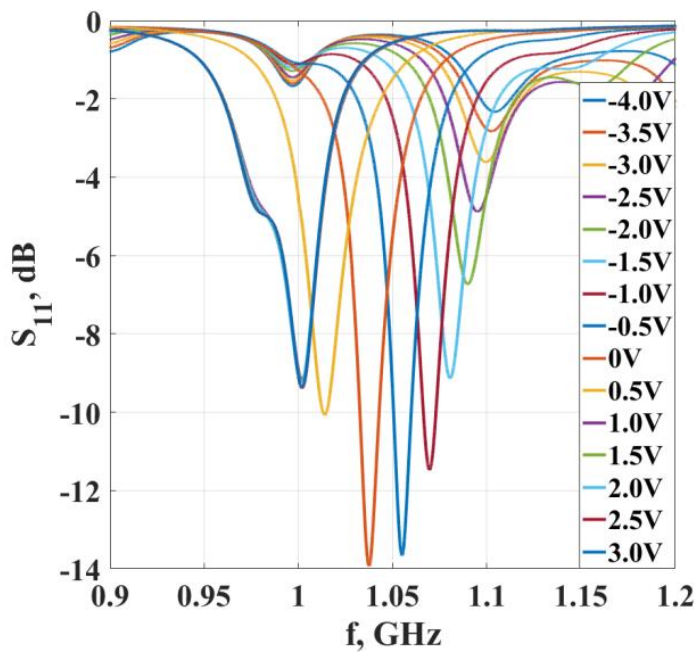

Fig. 3. Experimentally measured S11-parameters' frequency dispersion, which defines the operation frequency band of the investigated modulator setup. 
For the first experimental studying of the frequency modulation following the approach from Fig. 2, the harmonic signal $m(t)=\cos \left(2 \pi f_{m} t\right)$, where $f_{m}$ is the frequency of the modulation signal, was provided by generator $M S$. The amplitude values corresponded to the determined range above $\Delta U$ (Fig. 3). We investigated a number of harmonic signals with values of $f_{m}$ up to $10-20 \mathrm{MHz}$. Further increasing of $f_{m}$ is restricted by the characteristics of the varactor diode. The normalized power spectrum of modulated signal $S(t)$ with frequency $f_{m}=1 \mathrm{kHz}$ is shown in Fig. 5. It corresponds to the above-calculated deviation value and ratio (5).

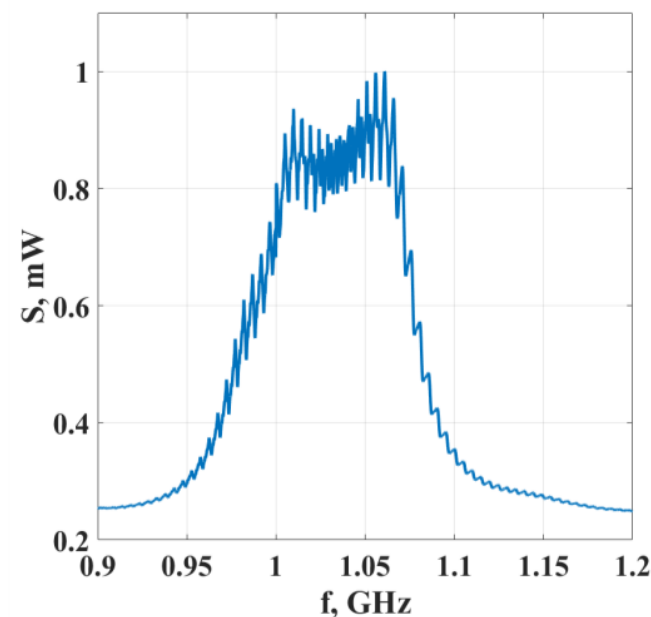

Fig. 4. Normalized to the maxima value power spectrum of the modulated harmonic signal

Investigation of the modulation of the broadband signal was carried out. Two different chaotic oscillations were utilized which are deterministic chaotic oscillations of Chua's scheme. These two signals are broadband and characterize continuous power spectra with $5 \mathrm{kHz}$ of bandwidth. The signals' amplitudes were controlled to not exceed the defined range of $\Delta U$. As a result, the normalized spectra of both modulated signals are shown in Fig. 5 which also satisfies the deviation value and ratio (5).

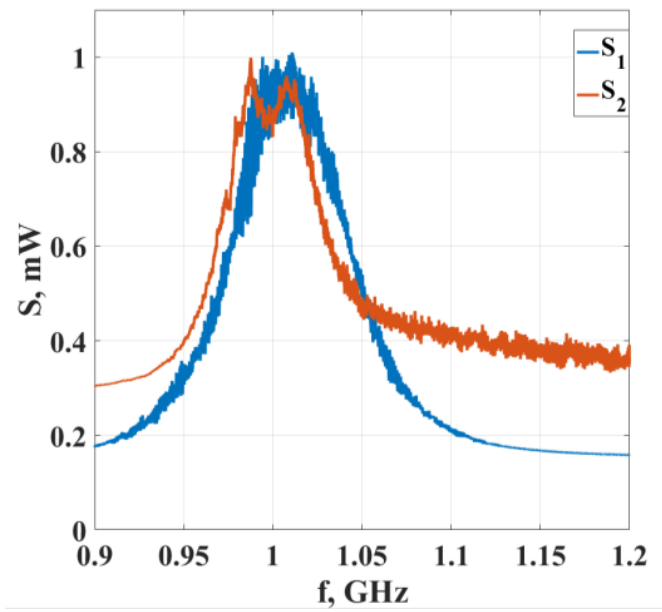

Fig. 5. Normalized to the maxima value power spectrum of the modulated deterministic chaotic signals

\section{Experimental investigation of demodulation}

Experimental investigation of the demodulation process was implemented through an IQ-demodulation scheme. Its equivalent circuit is shown in Fig. 6. The operational principle of the used IQ-demodulator is that a HF signal $S(t)$ from a radio channel splits between two branches of the circuit. The split signal $S_{I}(t)$ interacts with the HF signal $M_{l}(t)=\cos \left(2 \pi f_{c} t\right)$ via Mixerl and we receive the resulting signal $I(t)$ at the first output. Another split signal $S_{2}(t)$ mixes with the $90^{\circ}$-shifted $\mathrm{HF}$ signal that is $M_{2}(t)=\sin \left(2 \pi f_{c} t\right)$ via Mixerl and as a result, signal $Q(t)$ is received at the second output of the demodulator. $I(t)$ and $Q(t)$ are the components of complex value of the detected signal $M S$ and can be written as $m(t)=I(t)+i Q(t)$, where $i=\sqrt{ }(-1)$. In order to recover the initial modulation signal $m(t)$, it is necessary to determine the module of the detected signal as $m(t)=\sqrt{ }\left(I^{2}(t)+Q^{2}(t)\right)$.

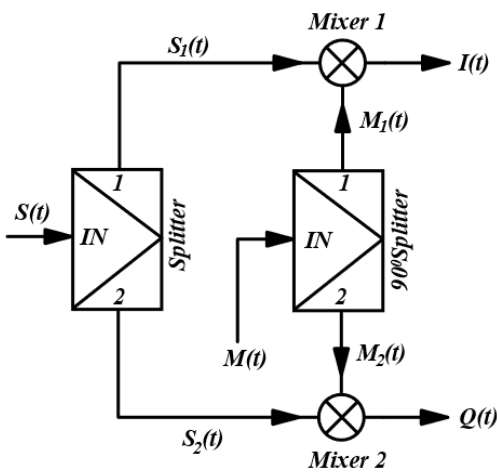

Fig. 6. Electrical circuit of IQ-demodulator that was utilized to recover the signal $m(t)$ modulated by the suggested approach $L F$

In the experimental process, we explored the modulation of a number of harmonic signals with different values of frequency up to the maximum possible. For presentation in this paper, we picked up the harmonic signal $m(t)$ at a $5 \mathrm{MHz}$ frequency. The experimentally obtained $I(t)$ and $Q(t)$ signal and their spectral characteristics are shown in Fig. 7 as a screen of the used oscilloscope. The obtained spectral characteristics contain the main harmonic component at the correct frequency.

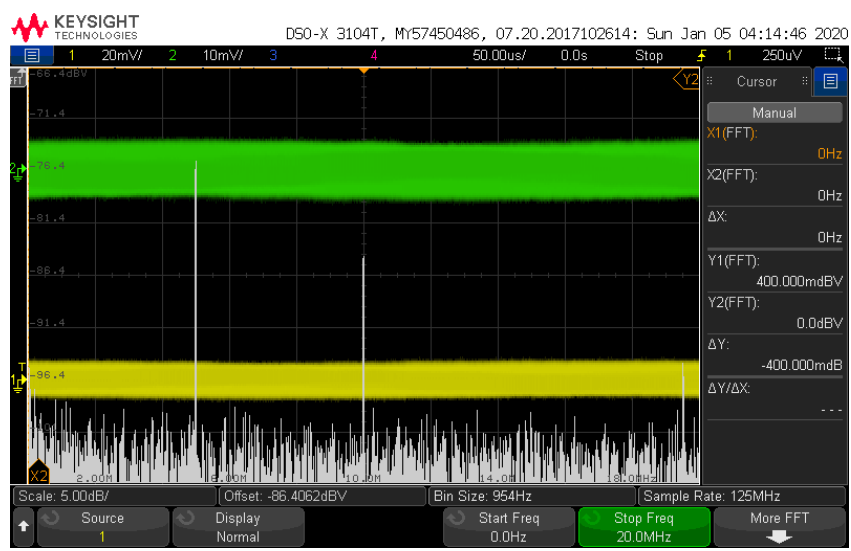

Fig. 7. Oscilloscope screen of time diagrams of the experimentally obtained I and $Q$ signals and their spectral characteristic for the modulation harmonic signal $m(t)$ with frequency $5 \mathrm{MHz}$

\section{Conclusions}

In this paper, a frequency modulation principle was suggested using an SRR loaded by a varactor diode. Changing of a bias voltage (LF modulation signal) of the utilized varactor diode allows the resonant parameters of the SRR oscillator to be tuned. The carrier signal was fed from a HF generator via an additional magnetic loop antenna through the strong near-field interaction with the SRR.

The experimental investigation was carried out for harmonic and chaotic (broadband) signal modulations. For the case where a SMV1231 varactor diode is used, the maximum range of frequency deviation $\Delta f_{d}= \pm 80 \mathrm{MHz}$ (the modulation index $\beta=0.078$ ) can be achieved, and for a $1 \mathrm{GHz}$ carrier signal, it occupies the frequency range $\Delta f=0.95 \ldots 1.11 \mathrm{GHz}$. However, the obtained spectrum band can be controlled and established by tuning the amplitude of the bias voltage.

We strongly believe that the presented investigation and obtained results are useful in the manufacturing of low-cost radio components. 


\section{References}

[1] Aydin K., Bulu I., Guven K., Kafesaki M., Soukoulis C. M., and Ozbay E. Investigation of magnetic resonances for different split-ring resonator parameters and design. New Journal of Physics 7(168)/2005, 1-15.

[2] Baraclough M., Hooper I. R., Barnes W. L.: Investigation of the coupling between tunable split-ring resonators. Physical Review B 98/2018, 085146.

[3] Binns K.J., Lawrenson P.J.: Analysis and Computation of Electric and Magnetic Field Problems. Pergamon International Library of Science, Technology, Engineering and Social Studies, 2013.

[4] Ebrahimi A., Withayachumnankul W., Al-Sarawi S., and Abbott D.: Highsensitivity metamaterial-inspired sensor for microfluidic dielectric characterization. IEEE Sensors Journal 14(5)/2014, 1345-1351.

[5] Freire M. J., Marques R., Jelinek L.: Experimental demonstration of a $\mu=-1$ metamaterial lens for magneticresonance imaging M. J. Freire. Applied Physic Letters 93/2008, 231108 (1-4).

[6] Gevorgian S. S. and Mironenko I. G.: Asymmetric coplanar-strip transmission lines for MMIC and integrated optic applications. Electron. Lett. 26(1916)/1990.

[7] Girich A.A.: Left-Handed Metamaterial based on the Complementary Split-Ring Resonators Tuned with Varactor Diodes. Ukrainian Journal of Physics 62(10)/2017, 903-907.

[8] Imade Y., Ulbricht R., Tomoda M., Matsuda O., Seiutinas G., Juodkazis S , Wright O.B.: Gigahertz Optomechanical Modulation by Split-Ring-Resonator Nanophotonic Meta-Atom Array. Nano Letters 17/2017, 6684-6689.

[9] Kitayama D., Yaita M., Song H.-J., Nosaka H.: High-Speed and High-ON/OFF Ratio Split-Ring-Resonator-Based Active Metamaterial using Varactor Diodes. 41st International Conference on Infrared, Millimeter, and Terahertz waves (IRMMW-THz), 2162-2035, 2016.

[10] Liang Y., Boon Ch., Li Ch. et al.: Design and Analysis of D-Band Om-Chip Modulator and Signal Source Based on Split-Ring Resonator. IEEE Transactions on Very Large Scale Integration Systems 27(7)/2019, 1513-1526.

[11] Liang Y., Yu H., Zhang W., Lin F.: CMOS Sub-THz On-Chip Modulator by Stacked Split Ring Resonator with High-extinction Ratio. IEEE International Symposium on Radio-Frequency Integration Technology 2015, 67-69.

[12] Liu P. et al.: Tunable meta-atom using liquid metal embedded in stretchable polymer. J. Appl. Phys. 118(1)/2015, 014504.

[13] Liu W., Sun H., Xu L.: A Microwave Method for Dielectric Characterization Measurement of Small Liquids Using a Metamaterial-Based Sensor. Sensor $18 / 2005,1438(1-10)$

[14] Marques R., Medina F., Rafii-el-Idrissi R.: Role of bianisotropy in negative permeability and left-handed metamaterials. Phys. Rev. B 65/2002, 144440 (16).

[15] Marques R., Baena J. D., Martel J., Medina F., Sorolla M., Martin F.: Nove small resonant electromagnetic particles for metamaterial and filter design. International Conference on Electromagnetic in Advanced Applications (ICEAA'03), Torino, Italy 2015, 439-442, 2005.

[16] Marques R., Martin F.: Wire media: Metamaterial Handbook. Theory and Phenomena of Metamaterials 2009. Chapter 16-1, CRC Press, Boca Raton.

[17] Marques R., Mesa F., Martel J., Medina F.: Comparative analysis of edge- and broadside- coupled split ring resonators for metamaterial design - theory and experiments. IEEE Transactions on Antennas and Propagation, 51/2003, 25722581

[18] Moser H.O., Casse B.D.F., Wilhelmi O., Saw B.T.: Terahertz Response of a Microfabricated Rod-Split_Ring Resonator Electromagnetic Metamaterial. Physical Review Letters 94/2005, 063901(1-4)

[19] Puentes M., Schubler M., Jakoby R.: 2D sensor array based on Split Ring Resonators for monitoring of organic tissue. Sensors 2011, 12491246.

[20] Rosa E. B.: The self and mutual inductances of linear conductors. Bulletin of the Bureau of Standards 4, 80/1908, 301-344.

[21] Salim A., Lim S.: Complementary Split-Ring Resonator-Loaded Microfluidic Ethanol Chemical Sensor. Sensors, 16/2016, 1802(1-13).

[22] Schuster Ch.: Fast and Accurate Tuning of a Cross-Coupled Split-Ring Resonator Filter. GeMiC-2018, March 12-14, 2018, Freiburg, Germany, 134137.

[23] Silva S. R., Shields A. D., Zhou J.: Tunable Optical Bistability and Optical Switching by Nonlinear Metamaterials. Material Science 2017.

[24] Veselago V. G.: The Electrodynamics of Substances with Simultaneously negative Values of $\varepsilon$ and $\mu$. Soviet Physics Uspekhi 10(4)/1967, 509-514.
[25] Vovchuk D., Khobzei M., Khavruniak M.: Sensing Properties of SRR: influence of finger touching. Int. Scientific-Practical Conference PIC S\&T'2019, 8-11 October 2019, Kyiv, Ukraine, 799-802.

[26] Wang Q., Mao D., Dong L.: Thermomechanically Tunable Infrared Metamaterials Using Asymmetric Split-Ring Resonators. Journal of Microelectromechanical Systems 26(6)/2017, 1-3.

[27] Ye-xin S., Jiu-sheng L., Le Z.: Graphene-integrated split-ring resonator terahertz modulator. Opt. Quant. Electron., 350/2017, 1-9.

[28] Zheludev N.I., Kivshar Yu.S.: From metamaterials to metadevices. Nature Materials 11/2012, 917-924.

[29] https://pdf1.alldatasheet.com/datasheetpdf/view/155289/SKYWORKS/SMV1231.html

\section{Ph.D. Dmytro Vovchuk}

e-mail:dimavovhuk@gmail.com

Teaching assistant at the Radio Engineering and Information Security Department of Yuriy Fedkovych Chernivtsi National University. Research field includes metamaterials, antennas and deterministic chaos for communications. Author of more than 20 publications.

http://orcid.org/0000-0001-7108-8984

\section{Ph.D. Serhii Haliuk}

e-mail: s.haliuk@chnu.edu.ua

Teaching assistant at the Radio Engineering and Information Security Department of Yuriy Fedkovych Chernivtsi National University. Research field covers the development of different components of hidden communication systems. Author of more than 20 publications.

http://orcid.org/0000-0003-3836-2675

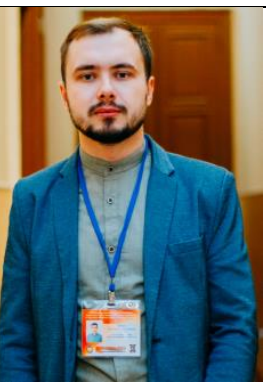

\section{M.Sc. Pavlo Robulets}

e-mail: pavel.robulets@gmail.com

Ph.D. student at the Radio Engineering and Information Security Department of Yuriy Fedkovych Chernivtsi National University. Research field includes metamaterials and communication systems for radio device applications. Author of more than 5 publications.
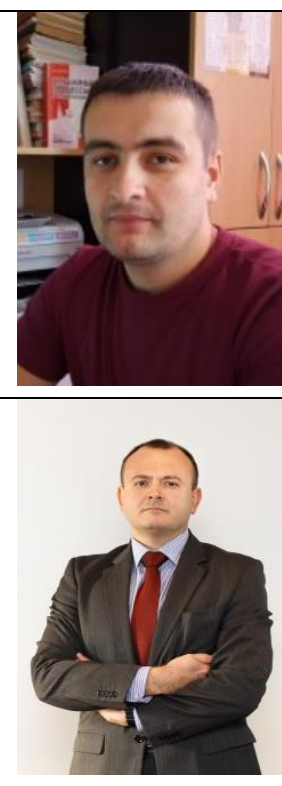

http://orcid.org/0000-0002-6089-482

\section{Prof. Leonid Politansky}

e-mail: rt-dpt@ @chnu.cv.ua

Yuriy Fedkovych Chernivtsi National University D.Sc. (technical), Professor, Head of the Department of Radio Engineering and Information Security. Research interests: physical processes in semiconductor devices, radio engineering devices and means of telecommunications. Author of nearly 200 publications in this research area.

http://orcid.org/0000-0001-6804-9837

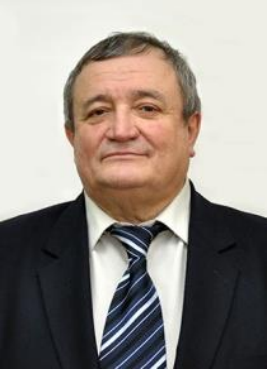

otrzymano/received: $21.05 .2020 \quad$ przyjęto do druku/accepted: 15.09 .2020 